Volume $\mathbf{4 9}$

Number 2

May 2015

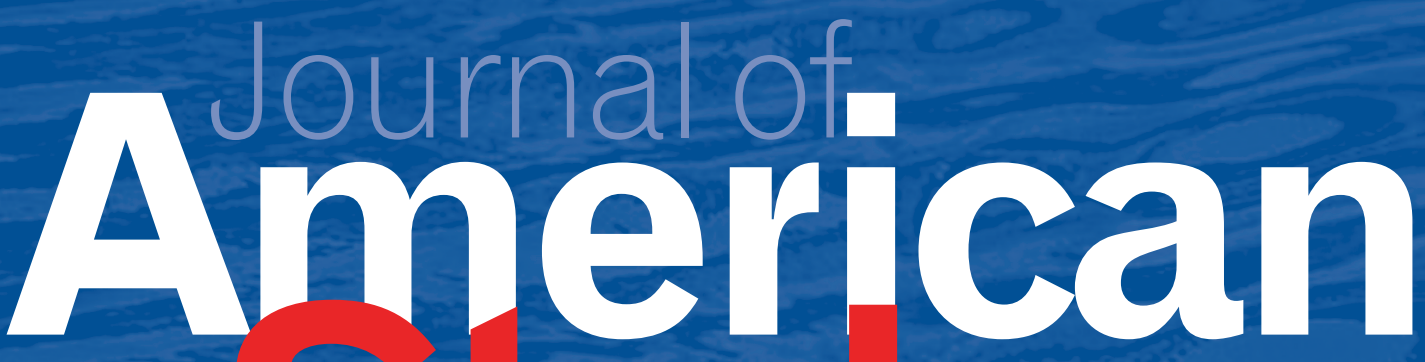

CAMBRIDGE

UNIVERSITY PRESS 
Celeste-Marie Bernier (Co-Editor)

University of Nottingham

Bevan Sewell (Co-Editor)

University of Nottingham

Sinéad Moynihan (Associate Editor)

University of Exeter

Nick Witham (Associate Editor)

Canterbury Christ Church University

Zalfa Feghali (Editorial Assistant) Canterbury Christ Church University

Sarah Daw (Editorial Assistant)

University of Exeter

\section{Bridget Bennett}

University of Leeds

Will Brooker

Kingston University London

Susan Currell

University of Sussex

Gary Gerstle

University of Cambridge

Alex Goodall

University College London

Richard Gray

University of Essex

Caroline Levander

Rice University

George Lewis

University of Leicester

Catherine Morley

University of Leicester

Brian Neve

University of Bath

Sarah Pearsall

University of Cambridge

\section{Geoff Plank}

University of East Anglia

Theresa Saxon

University of Central Lancashire

\section{Daniel Scroop}

University of Glasgow

Marjorie Spruill

University of South Carolina

Fionnghuala Sweeney

University of Newcastle

Jenny Terry

Durham University

Stephen Tuck

University of Oxford

Mark Whalan

University of Oregon

Hugh Wilford

California State University

\section{American \\ Studies}

\section{Subscriptions}

Journal of American Studies is published four times a year in February, May, August and November. The subscription price (excluding VAT), which includes postage, of Volume 49, 2015, is $£_{326} 6$ (USA, Canada and Mexico US \$568), for institutions print and electronic, institutions electronic only $£ 276 / \$ 480$; individual rates are available on application to the publisher. Single parts are available at £go net (USA, Canada and Mexico \$156) each. Orders, which must be accompanied by payment, may be sent to a bookseller, subscription agent or to the publishers: Cambridge University Press, Journals Fulfillment Department, UPH, Shaftesbury Road, Cambridge CB2 8BS, UK or in the USA, Canada and Mexico to Cambridge University Press, The Journals Fulfillment Department, Ioo Brook Hill Drive, West Nyack, New York I0994-2133. EU subscribers (outside the UK) who are not registered for VAT should add VAT at their country's rate. VAT registered subscribers should provide their VAT registration number. Japanese prices for institutions are available from Kinokuniya Company Ltd,

P. O. Box 55, Chitose, Tokyo 156, Japan. Prices include delivery by air. Copies of the Journal for subscribers in the USA, Canada and Mexico are sent by air to New York to arrive with minimum delay.

\section{Copying}

This journal is registered with the Copyright Clearance Center, 222 Rosewood Drive, Danvers, MA O1923. Organizations in the USA who are also registered with CCC may therefore copy material (beyond the limits permitted by sections I07 and IO8 of US Copyright law) subject to payment to CCC of the per copy fee of \$I2.00.

This consent does not extend to multiple copying for promotional or commercial purposes. Code OO2I-8758/2013/BAAS-OOOI \$I2.00. ISI Tear Sheet Service, 350I Market Street, Philadelphia, Pennsylvania I9IO4, USA is authorized to supply single copies of separate articles for private use only.

Organizations authorized by the Copyright Licensing Agency may also copy material subject to the usual conditions. For allother use, permission should be sought from Cambridge or the American Branch of Cambridge University Press.

Claims for missing issues will be considered only if made immediately upon receipt of the subsequent issue.

\section{Internet access}

This journal is included in the Cambridge Journals Online service which can be found at http://journals.cambridge.org. For further information on other Press titles access http://www.cambridge.org

\section{Book Reviews}

Editorial correspondence relating to book reviews should be sent to Dr Sinéad Moynihan, Department of English, University of Exeter, The Queen's Building, The Queen's Drive, Exeter EX4 4QJ, UK, jasreviews@exeter.ac.uk

The British Association for American Studies (BAAS) was founded in 1955 to promote the study of the United States within the United 


\section{Contents}

Editors' Note

"It Will Come at Last": Acts of Emancipation in the Art,

Culture and Politics of the Black Diaspora

FiONNGHUALA SWEENEY

\section{Articles}

Locating History within Fiction's Frame: Re-presenting the Epopée Delgrès in Maximin and Lara

H. AdLai Murdoch

Ecological Chains of Unfreedom: Contours of Black Sovereignty in the Atlantic World

KAREN N. SALT

New England's Fortune: An Inheritance of Black Bodies and Bones

P. GABRIELLE Foreman

John Brown's Spirit: The Abolitionist Aesthetic of

Emancipatory Martyrdom in Early Antilynching Protest Literature

Zoe TRODD

A Visual Call to Arms against the "Caracature [sic] of My Own

Face:" From Fugitive Slave to Fugitive Image in Frederick Douglass's Theory of Portraiture

Celeste-Marie Bernier

"In the Free": The Work of Emancipation in the Anglo-

Caribbean Historical Novel

CANDACE WARD

Slavery and Syncretic Performance in the Noite do Tambores

Silenciosos: Or How Batuque and the Calunga Dance around with the Memory of Slavery

Marcus WoOd

\section{Review Essay}

Recent Music History Scholarship: Pleasures and Drawbacks 


\section{Reviews}

Courtney B. Ryan, Ariel's Ecology: Plantations, Personhood, and Colonialism in the American Tropics

Sam W. Haynes, The American Idea of England, ${ }_{1776-1840: \text { Transatlantic }}$ Writing

Jeffrey S. Selinger, Era of Experimentation: American Political Practices in the Early Republic

Vincent Carretta, Slave Portraiture in the Atlantic World

Darcy A. Zabel, Making Freedom: The Underground Railroad and the Politics of Slavery

Kieran Quinlan, The Green and the Grey: The Irish in the Confederate States of America

Carolyn Eastman, The Cosmopolitan Lyceum: Lecture Culture and the Globe in Nineteenth-Century America

Antonio Barrenechea, Race, Romance, and Rebellion: Literatures of the Americas in the Nineteenth Century

Deborah Toner, The Politics of Probibition: American Governance and the Prohibition Party, I860-1933

Sinéad Moynihan, Kinship and Performance in the Black and Green Atlantic

David McCarthy, The Degenerate Muse: American Nature, Modernist Poetry, and the Problem of Cultural Hygiene

Ian F. A. Bell, Ezra Pound's Eriugena

Graeme Abernethy, F. Scott Fitzgerald's Fiction: "An Almost Theatrical Innocence"
4 I 3
Christina D. Abreu, Race and Displacement: Nation, Migration, and Identity in the Twenty-First Century

Alan Wald, Ain't Got No Home: America's Great Migrations and the Making of an Interracial Left

Maxine Craig, Pageants, Parlors, \& Pretty Women: Race and Beauty in the Twentieth-Century South

Jack Glazier, After They Closed the Gates: Jewish Illegal Immigration to the United States, I92I-I965 and In the Shadow of Hitler: Alabama's Jews, the Second World War, and the Holocaust

Beth Montemurro, As Long as We Both Shall Love: The White Wedding in Postwar America

Jennifer Walton, John F. Kennedy and Kennedy: A Cultural History of an American Icon

Will Kaufman, The Pete Seeger Reader

Alvita Akiboh, Islands of Empire: Pop Culture and U.S. Power

Jeffrey Geiger, Puro Arte: Filipinos on the Stages of Empire

Bevan Sewell, Body and Nation: The Global Realm of U.S. Body Politics in the Twentieth Century

Kai Chen, Looking for Balance: China, the United States, and Power Balancing in East Asia

Robert Mason, The Eclipse of America: Arguing America on Meet the Press

Daniel Mattingly, Understanding Michael Chabon

Brooke Beloso, Other Dreams of Freedom: Religion, Sex, and Human Trafficking

\section{Electronic content}

Review Essay

Disorder and Early Sorrow

Peter A. Coclanis 


\section{Exclusive Online Reviews}

The following reviews are freely available in the online version of this issue at www.journals. cambridge.org/ams

Lucas Richert, Native Diasporas: Indigenous Identities and Settler Colonialism in the Americas

Tim Lockley, Free Black Communities and the Underground Railroad: The Geography of Resistance

Michael Todd Landis, Washington Brotherhood: Politics, Social Life, and the Coming of the Civil War

R. J. Wilson, From These Honored Dead: Historical Archaeology of the American Civil War

Anne-Claire Faucquez, Stuyvesant Bound: An Essay on Loss across Time

Diana L. Ahmad, The Road to Chinese Exclusion: The Denver Riot, I 880 Election, and Rise of the West

Donna T. Haverty-Stacke, Red Apple: Communism and McCarthyism in Cold War New York

Peter Iverson, Reimagining Indian Country: Native American Migration and Identity in Twentieth-Century Los Angeles

Erin Penner, Death and the Moving Image: Ideology, Iconography and I

Brenna Wynn Greer, Freedom Now! Forgotten Photographs of the Civil Rights Struggle

Dionne Espinoza, Sancho's Journal: Exploring the Political Edge with the Brown Berets

Justine Tally, Toni Morrison and the Classical Tradition

Kyle William Bishop, "We're All Infected": Essays on AMC's The Walking Dead and the Fate of the Human

Judie Newman, Contemporary ArabAmerican Literature: Transnational Reconfigurations of Citizenship and Belonging

Robin Li, The Color of Success: Asian Americans and the Origins of the Model Minority

Loch K. Johnson, The Family Jewels: The CIA, Secrecy, and Presidential Power

Claudia Hillebrand, In Spies We Trust: The Story of Western Intelligence

Patrick Andelic, The Making of a Southern Democracy: North Carolina Politics from Kerr Scott to Pat McCrory

Colin Reynolds, Conservative Bias: How Jesse Helms Pioneered the Rise of RightWing Media and Realigned the Republican Party

John E. Owens American Public Opinion, Advocacy, and Policy in Congress: What the Public Wants and What It Gets 


\section{Editors' Note}

We are delighted in this issue to feature a special collection of essays edited by Fionnghuala Sweeney and Karen Salt on "Acts of Emancipation in the Art, Culture and Politics of the Black Diaspora." Consisting of seven essays plus a feature-length introduction, the articles consider a number of different ways in which acts and arts of emancipation have been remembered and understood. Showcasing the exciting range of new scholarship that is emerging in the related fields of African American studies, African diasporic studies, slavery studies and American studies, among many more, this special issue adopts an interdisciplinary framework to excavate the stories of actors so often marginalized and underrepresented. As Sweeney writes toward the end of her introduction, the essays all "prompt consideration of the kinds of symbolic and political acts that capture what it meant to be involved in emancipation more broadly, of deeds of justice and humanity, great and small, that have deeper psychological, sociological and political meaning for our understanding of emancipation than is often thought," and "emphasize that elaboration of the philosophical, political, existential and aesthetic questions around the nature of freedom and the nature of emancipation continues to be necessary."

On the review side, we feature two review essays. In the first, "Recent Music History Scholarship: Pleasures and Drawbacks," Harvey Cohen examines a range of recent works on American music as he investigates core debates related to race, jazz and American cultural history. He sheds powerful light on the extent to which "African American history, with its dramatic arcs of repression and redemption, has served as a particularly fruitful area for such scholarship". In the second, "Disorder and Early Sorrow," Peter Coclanis provides a detailed response to Joshua Rothman's groundbreaking book Flush Times and Fever Dreams: A History of Capitalism and Slavery in the Age of Jackson. In addition, we also feature an array of reviews that cover a range of topics from the course of American politics in the early republic, to representations of death in film, pop culture and American empire, to perceptions of communists in Cold War New York. 